\title{
Glacier variations and climate change in the central Himalaya over the past few decades
}

\author{
REN Jiawen, ${ }^{1,2}$ JING Zhefan, ${ }^{1}$ PU Jianchen, ${ }^{1}$ QIN Xiang ${ }^{1}$ \\ ${ }^{1}$ Laboratory of Cryosphere and Environment, Cold and Arid Regions Environmental and Engineering Institute, \\ Chinese Academy of Sciences, 260 Donggang West Road, Lanzhou 730000, China \\ E-mail: jwren@Izb.ac.cn \\ ${ }^{2}$ Institute of Tibetan Plateau Research, Chinese Academy of Sciences, Beijing 100029, China
}

\begin{abstract}
Glacier variation is one of many indicators of climate change. Repeat measurements of the glacier terminus positions for selected glaciers in the central Himalaya document that they have been in a state of continuous retreat over the past few decades. Since the 1960s the average retreat rate on the north slope of Qomolangma (Mount Everest) is 5.5-9.5 $\mathrm{ma}^{-1}$ and on Xixiabangma it is $4.0-5.2 \mathrm{~m} \mathrm{a}^{-1}$. Many glaciers on the south slope of the central Himalaya have been in retreat, and recently their retreat rate has accelerated. Ice-core studies show that the annual accumulation on these glaciers has fluctuated, but over the last century it has declined. It decreased rapidly in the 1960s and has remained consistently below the long-term mean thereafter. Meteorological station records indicate that the annual mean temperature in the region has slowly increased, particularly during the summer months. The strongest warming has occurred in the last 30 years. These data suggest that the current glacier retreat is due to the combined effect of reduced precipitation and warmer temperatures, and, if these conditions continue, the glaciers in the region will continue to shrink.
\end{abstract}

\section{INTRODUCTION}

Since climate change has a profound influence on the environment that sustains life, the warming in the second half of the 20th century has important implications for publicly shared resources and public policy. Over the past century, one of the best-documented trends is the increase in the Earth's globally averaged near-surface temperature (Houghton and others, 2001). However, regional temperature trends show marked differences. For instance, warming trends have been greater in western China than in eastern China (Qin, 2005). Precipitation usually exhibits much greater spatial variability, such that regional differences are even more variable and complex than those of temperature. It has been reported that the climate in northwestern China is becoming both warmer and wetter (Shi and others, 2002; Shi, 2003), while the trends are less clear in southwestern China.

The near-global-scale retreat of glaciers during the last few decades is frequently mentioned as a clear and unambiguous sign of increasing temperatures (Houghton and others, 2001; Oerlemans, 2005). The Tibetan Plateau is one of the important glacierized regions in the middle and

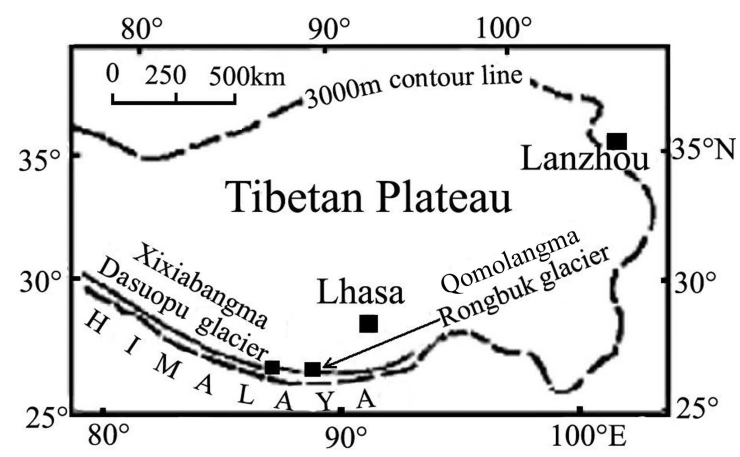

Fig. 1. A sketch map showing the location of Qomolangma and Xixiabangma. low latitudes, where glacier retreat appears to be prevalent (Yao and others, 2004). Glacier variations and climate changes in the central Himalaya along the southern margin of the Tibetan Plateau are particularly interesting, as these are among the Earth's highest peaks and the regional precipitation is dominated by the monsoon system. Here, meteorological stations are sparse, with relatively short-term instrumental records, but these have been augmented by ice-core records from glaciers on Qomolangma (Mount Everest) and Xixiabangma in the central Himalaya (Fig. 1). The ice-core records suggest that annual net accumulation has been decreasing over the last century (Hou and others, 2000; Qin and others, 2000; Thompson and others, 2000; Yao and others, 2000; Duan and others, 2002), while at the same time temperatures (inferred from stable-isotopic ratios) have been increasing (Thompson and others, 2000; Yao and others, 2002). The degree to which stable-isotopic ratios reflect temperature and over what timescales this relationship may be valid remain open for debate (Zhang and others, 2003). Although glacier mass balances and variations in the terminus positions have not been systematically and continuously monitored, the relative positions of some glacier margins have been measured during ice-core drilling programs. These have been compared to observations made by earlier field parties. Comparisons of glacier terminal positions in different years allow a general estimation of recent glacier changes in this region. Here we present the available data for five different glaciers in the central Himalaya and we discuss the possible climatic drivers responsible for the observed changes.

\section{OBSERVATION RESULTS OF GLACIER VARIATION}

The term glacier variation is very general and may refer to various observations that include changes in length, width, thickness, area and total volume. However, only rarely are 


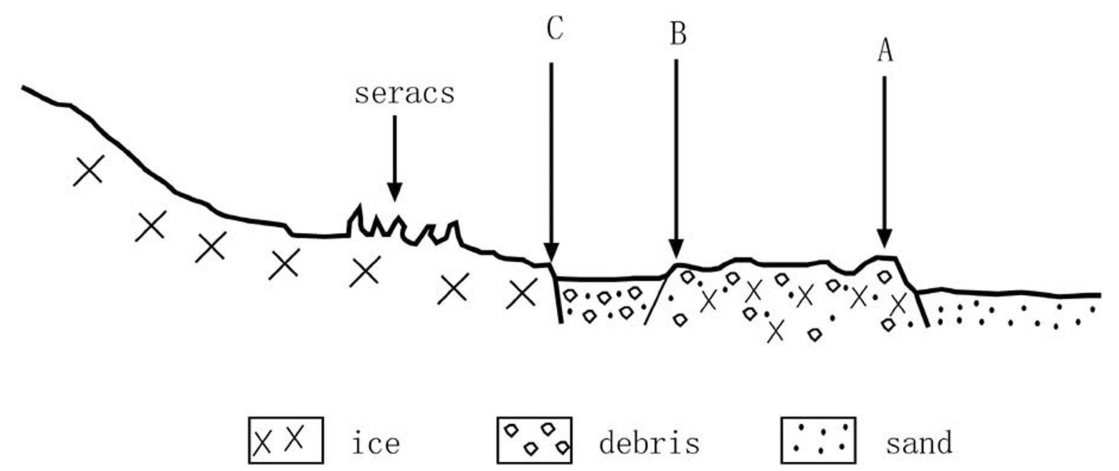

Fig. 2. A sketch of the surface profile near the Middle Rongbuk Glacier terminus.

all the components necessary to determine volume changes obtained, due to the rigors of the field site or the length of time available for the measurements. Often these observations are made opportunistically. The most common observation is the position of the glacier terminus, such that changes over time are inferred to represent variations in glacier length.

Field investigations and inventory data from the 1950s to the 1980s (Ren, 1988) suggest that most of the glaciers in the Himalaya within the boundaries of China have been retreating over the last 50 years. In the central Himalaya, the glaciers on Qomolangma and Xixiabangma have been measured several times over the past few decades.

The first survey and mapping with high precision was done on Qomolangma in 1966. Since 1997, the boundary between the debris-covered ice and debris-free areas of both Rongbuk and East Rongbuk Glaciers has been measured six times, and for Far East Rongbuk Glacier it has been measured twice. On Xixiabangma, the termini of two glaciers were measured twice (Table 1 ). These data allow the retreat of the termini and/or the near-terminal position (see discussion below) to be determined.

On the lower part of Rongbuk Glacier, there is a debriscovered area; the section A-B (Fig. 2) is very rough, covered by a debris layer and a number of small pools of water. The buried ice beneath the debris layer seems to be stable, suggesting that the debris-covered area has not changed greatly since the 1966 observations. In 1966, section B-C (Fig. 2) was a debris-free area, but in 1997 it was observed to be a flat debris-covered area with a surface that is lower than that of section A-B. It appears that no ice remains under section $\mathrm{B}-\mathrm{C}$. Henceforth, section $\mathrm{B}-\mathrm{C}$ has enlarged continuously but point B has not changed. Therefore, we interpret the position denoted as $\mathrm{C}$ to be the present terminus of this glacier. Thus, the glacier terminus retreat data in Table 2 were measured relative to point $C$. The other glaciers in Table 2 did not have a debris cover.

Comparisons of the terminus positions measured in different years (Table 1) show that all five glaciers have been continuously retreating since the initial observation. On Qomolangma the near-terminus retreat rate from 1966 to 1997 was 8.7, 5.5 and $7.4 \mathrm{ma}^{-1}$ for Rongbuk Glacier and East and Far East Rongbuk Glaciers, respectively. Between 1997 and 2004 the retreat of these glaciers accelerated slightly (Table 1). On Xixiabangma, Kangwure glacier retreated at a rate of $5.23 \mathrm{~m} \mathrm{a}^{-1}$ from 1991 to 2001, while a branch of Dasuopu glacier retreated at an average rate of $4.0 \mathrm{~m} \mathrm{a}^{-1}$ from 1968 to 1997 ( $\mathrm{Pu}$, personal observation). It is reported that the glaciers on the south slope of Qomolangma have also retreated over the last few decades, and that the rate of retreat appears to have accelerated since the 1980s (Fujita and others, 1997, 1998, 2001; Kadota and others, 1997; Yamada and others, 1992; Seko and others, 1998).

Table 1. Observed retreat rates of glacier terminus positions on Qomolangma and Xixiabangma

\begin{tabular}{|c|c|c|c|c|c|c|c|}
\hline Glacier & Location & $\begin{array}{l}\text { Length } \\
\text { km }\end{array}$ & $\begin{array}{l}\text { Area } \\
\mathrm{km}^{2}\end{array}$ & $\begin{array}{c}\text { Terminus } \\
\text { ma.s.l. }\end{array}$ & Period & Measurement time & $\begin{array}{c}\text { Retreat rate } \\
\mathrm{m} \mathrm{a}^{-1}\end{array}$ \\
\hline \multicolumn{8}{|l|}{ Qomolangma } \\
\hline \multirow[t]{4}{*}{ Rongbuk } & $28^{\circ} 02^{\prime} \mathrm{N}, 86^{\circ} 51^{\prime} \mathrm{E}$ & 22.4 & 85.4 & 5200 & 1966-97 & 1966, 1997 & 8.7 \\
\hline & & & & & 1997-99 & 1997, 1999 & 8.9 \\
\hline & & & & & 1999-2002 & Every year & 9.1 \\
\hline & & & & & $2002-04$ & 2002,2004 & 9.5 \\
\hline \multirow[t]{4}{*}{ East Rongbuk } & $28^{\circ} 02^{\prime} \mathrm{N}, 86^{\circ} 57^{\prime} \mathrm{E}$ & 12.8 & 46.27 & 5560 & 1966-97 & 1966,1997 & 5.5 \\
\hline & & & & & 1997-99 & 1997, 1999 & 7.6 \\
\hline & & & & & 1999-2002 & Every year & 8.0 \\
\hline & & & & & 2002-04 & 2002, 2004 & 8.3 \\
\hline $\begin{array}{l}\text { Far East Rongbuk } \\
\text { Xixiabangma }\end{array}$ & $28^{\circ} 02^{\prime} \mathrm{N}, 86^{\circ} 57^{\prime} \mathrm{E}$ & 7.1 & & 6180 & 1966-97 & 1966, 1997 & 7.4 \\
\hline Kangwure & $28^{\circ} 27^{\prime} \mathrm{N}, 85^{\circ} 50^{\prime} \mathrm{E}$ & 3.1 & 2.27 & 5675 & 1991-2001 & 1991, 2001 & 5.2 \\
\hline
\end{tabular}

*The Far East Rongbuk is part of the East Rongbuk. 'From Yao and others (1999). 

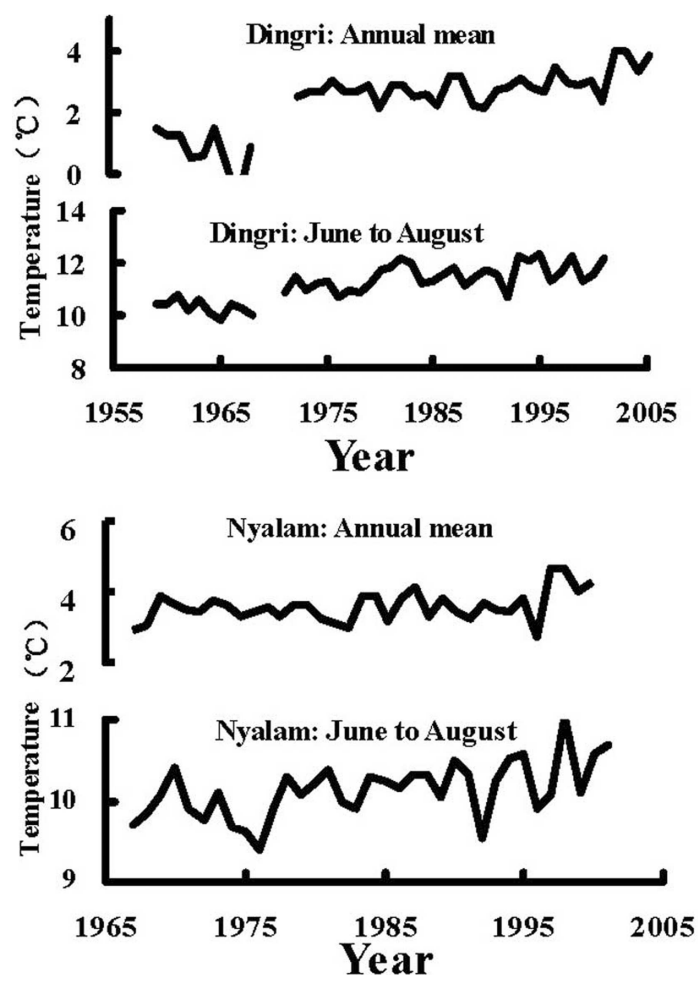

Fig. 3. The annual and the summer (June-August) mean temperatures at Dingri and Nyalam meteorological stations.

\section{PRECIPITATION CHANGES DERIVED FROM ICE CORES}

In 1997, three ice cores from Dasuopu glacier were drilled to depths of 149-168 m (Thompson and others, 2000; Yao and others, 2002). Several cores have also been drilled to depths of 40-120 m on East Rongbuk and Far East Rongbuk Glaciers on Qomolangma (Hou and others, 2000; Qin and others, 2002). The analyses of these cores yielded multicentury records of climate changes (net accumulation and isotopically inferred temperatures) for the middle part of the Himalaya. These records are important, as they provide a paleoclimatic context that should help understand the processes driving the currently observed glacier retreat in the region.

At these high-elevation drill sites it is very cold, and snowmelt is minimal. Thus little mass is lost from the annual accumulation layer that is gradually thinned by steady vertical compression. Some mass might be removed by wind scour, but there is no way to control for this effect. Thus the annual layer thicknesses (in meters of water equivalent) are assumed to approximate the net annual accumulation or possibly the local annual precipitation, particularly when averaged over multiple years and decades. A 400 year record of accumulation rate derived from the Dasuopu ice cores (Yao and others, 2000; Duan and others, 2002, 2004) indicates that the annual accumulation rate has decreased continuously since 1930. Similar records from the 40 and $80 \mathrm{~m}$ cores from Qomolangma indicate that the annual accumulation rate decreased rapidly from the 1950 s to the 1960s, remained constant until the 1980s, then decreased up to the present (Hou and others, 1999; Qin and others, 2002).

Precipitation in the region comes mainly via the Indian monsoon, so changes in net accumulation should at least partially reflect monsoonal variations. Monsoon precipitation exhibits large spatial variability. Duan and others (2002) and K. Duan (unpublished information) have compared the annual accumulation time series from the Dasuopu ice cores over the past 300 years and precipitation records in various regions of India over the last century. Their comparative study confirmed that the ice-core-derived accumulation rate variations are consistent with precipitation variations in the northern, and especially the northeastern, Indian Peninsula. Zhang (2002) reached a similar conclusion using the accumulation histories from the Qomolangma ice cores. These data suggest that precipitation trends in the central Himalaya are dominated by northeastern Indian monsoon precipitation.

\section{TEMPERATURE CHANGE}

Thompson and others (2000) found that over relatively long timescales (decades to century) the trend in $\delta^{18} \mathrm{O}$ from the Dasuopu ice core is similar to that of the Northern Hemisphere temperature history. This leads them to suggest that the $\delta^{18} \mathrm{O}$ profiles from Himalayan ice cores might reflect long-term changes in temperature. Yao and others (2002) discussed temperature changes over the past $2 \mathrm{kyr}$ as inferred from the Dasuopu $\delta^{18} \mathrm{O}$ profiles, and identified two very prominent warm periods: the Medieval Warm Period and a continuous increase in temperature since $\sim 1850$. In contrast, a monitoring study that compared the stableisotopic ratios in rainfall at various sites over the Tibetan Plateau (Tian and others, 2001, 2003) with precipitation and snow layers on glaciers on Qomolangma and Xixiabangma (Kang and others, 2000; Qin and others, 2000, 2002; Zhang, 2001; Zhang and others, 2003) showed that on very short timescales the $\delta^{18} \mathrm{O}$ composition of the rainfall over the southern Tibetan Plateau reflects mainly the 'precipitation amount effect', i.e. the higher the amount of monsoon precipitation, the lower (more negative) the isotopic ratio. Therefore, it seems unreasonable to interpret changes in the ice-core $\delta^{18} \mathrm{O}$ profile as indicative of only temperature changes on annual to decadal timescales.

Thus the question arises as to whether temperature has increased in the central Himalaya in the past few decades as inferred from the ice-core $\delta^{18} \mathrm{O}$ records. Meteorological station data reveal that this is the case. Figure 3 shows the annual and summer (June-August) mean temperatures from the meteorological stations at Dingri (4300 ma.s.l.), located $\sim 80 \mathrm{~km}$ northeast of Qomolangma, and Nyalam (3800 ma.s.l.), located $\sim 40 \mathrm{~km}$ southeast of Xixiabangma. The full observational period is shown for both stations. The four decades of data from Dingri (Fig. 3) reveal the lowest temperatures in the 1960s and continuously increasing temperatures since the 1970s. Annual and summer temperatures show similar trends, but in the late 1990s the annual average temperatures increased rapidly while summer temperatures continued to increase more slowly. At Nyalam, annual average temperatures showed little change from the 1960 s to the 1990s, but increased abruptly thereafter. Interestingly, summer temperatures increased continuously over the observation period. In general, the range of temperatures over this period is larger at Dingri than at Nyalam. The Nyalam station is located in a river valley with plentiful precipitation, while Dingri station is located in an arid mountain zone. This is as expected since the 
temperature ranges over the course of a year are smaller in moist regions than in arid regions (Ahrens, 1994).

Moreover, from the Assessment Report of Climate and Environment Changes in West China (Qin, 2002) and the Intergovernmental Panel on Climate Change (IPCC) Third Assessment Report (Houghton and others, 2001), the increase in annual temperatures has been widespread in southwest China over the past 50 years and in south Asia since 1976. In addition, the recent large-scale retreat of glaciers on the southern slopes of the Himalaya suggests that rising temperatures may play an important role.

\section{DISCUSSION}

As discussed above, observations suggest that glacier recession in the central Himalaya may be the result of both a decrease in precipitation and an increase in temperature. Unfortunately, the relative importance of temperature and precipitation cannot be assessed at this time due to the small number of available meteorological records, their relatively short length and the very limited number of glacier massbalance observations in the remote Himalayan region.

Although glaciers inevitably respond to climate changes that affect their mass balance, the response time can vary from glacier to glacier. For most mountain glaciers, the delay time is $<10$ years (Paterson, 1994), but the response time, i.e. the time a glacier takes to adjust to a change in mass balance, is longer. The response time depends on the glacier dimensions, especially on its length, as well as on the basic physical characteristics of the glacier such as velocity and rates of ablation. For valley glaciers, the response time is believed to be on the order of several decades (Paterson, 1994). In the case of Rongbuk Glacier, for example, the response time can be estimated very roughly if we take the simplest formula introduced by Paterson (1994): $t=1.5 \mathrm{~h} / \mathrm{a}_{0}$ or $t=L /\left(2 u_{0}\right)$, where $t$ is the response time (years), $h$ is the average thickness, $a_{0}$ is the ablation rate at the glacier terminus $\left(\mathrm{m} \mathrm{a}^{-1}\right), L$ is the glacier length, and $u_{0}$ is the velocity at the terminus. The length of Rongbuk Glacier is $22.4 \mathrm{~km}$, and the average value of the surface velocity is a little more than $20 \mathrm{~m} \mathrm{a}^{-1}$ in the ablation area and about $10 \mathrm{~m} \mathrm{a}^{-1}$ at the terminus. However, for large glaciers, such as Rongbuk and Dasuopu glaciers, basal sliding may in part determine the ice velocity (Shi and others, 1988). The ablation rate at the terminus is $2-3 \mathrm{~m} \mathrm{a}^{-1}$. Although the ice thickness has not been measured, the average thickness is likely to be $<120 \mathrm{~m}$ because the deepest ice-core drilling to bedrock in the accumulation area is about $120 \mathrm{~m}$. If we take the average thickness as $80-120 \mathrm{~m}$, the response time, is estimated to lie somewhere between 40 and 120 years. It is shorter for the other glaciers in Table 1. Thus it is likely that the glaciers in the central Himalaya are still responding to changes in their regional climate that occurred several decades ago.

This estimate is based on an ideal assumption that the mass balance remains steady at the new value (mass balance) until the response ends. In reality, climate, and hence glacier mass balance, do not remain constant for long time periods. In this region, as mentioned above, temperatures have been increasing while precipitation has been decreasing over the past few decades. Consequently, not only the glacier mass balance but also the ice velocity undergoes continuous change. Therefore, the response time is likely to be shorter than the value above that was estimated using the simple formula. The situation is actually more complex, as warmer temperatures are likely to lead to increased meltwater production that may increase the ice velocity, which will further shorten the response time. For further discussion, particularly for modeling response times, detailed observations of many glacier parameters are needed.

According to recent comprehensive studies of climate in western China (Wang and others, 2002; Zhao and others, 2002), temperatures are expected to increase in the near future. As the accumulation rate inferred from ice-core records has been shown to be highly negatively correlated with Northern Hemispheric temperatures (Thompson and others, 2000; Yao and others, 2000; Duan and others, 2002; K. Duan, unpublished information), it is possible that the warm-dry trend in the central Himalaya will continue in concert with the projected global temperature trends, and glacier retreat in the region may accelerate. Even if the trend toward warmer and dryer conditions reverses toward colder and drier or colder and wetter conditions, the glaciers in the region should continue to retreat for some time into the future due to the time needed to respond to the change in the climate regime.

\section{ACKNOWLEDGEMENTS}

This work was supported by the Chinese Academy of Sciences (grant No. KZCX2-SW-118 and KZCX3-SW-235). Special thanks to K. Fujita and an anonymous reviewer for helpful comments and suggestions, and to L. Thompson, $\mathrm{H}$. Brecher and E. Mosley-Thompson for improving the manuscript.

\section{REFERENCES}

Ahrens, C.D. 1994. Meteorology today: an introduction to weather, climate, and the environment. Fifth edition. Minneapolis, MN/St Paul, MN: West Publishing.

Duan, K., T. Yao, J. Pu and W. Sun. 2002. Response of monsoon variability in Himalayas to global warming. Chinese Sci. Bull., 47(21), 1842-1845.

Duan, K., T. Yao and L.G. Thompson. 2004. Low-frequency of southern Asian monsoon variability using a 295-year record from the Dasuopu ice core in the central Himalayas. Geophys. Res. Lett., 31(16), L16209. (10.1029/2004GL020015.)

Fujita, K., M. Nakawo, Y. Fujii and P. Paudyal. 1997. Change in glaciers in Hidden Valley, Mukut Himal, Nepal Himalayas, from 1974 to 1994. J. Glaciol., 43(145), 583-588.

Fujita, K., N. Takeuchi and K. Seko. 1998. Glaciological observations of Yala Glacier in Langtang Valley, Nepal Himalayas, 1994 and 1996. Bull. Glacier Res., 16, 75-81.

Fujita, K., T. Kadota, B. Rana, R.B. Kayastha and Y. Ageta. 2001. Shrinkage of Glacier AX010 in Shorong region, Nepal Himalayas in the 1990s. Bull. Glacier Res., 18, 51-54.

Hou, S., D. Qin, C.P. Wake and P.A. Mayewski. 1999. Correspondence. Abrupt decrease in recent snow accumulation at Mount Qomolangma (Everest), Himalaya. J. Glaciol., 45(151), 585-586.

Hou, S., D. Qin, C.P. Wake, P.A. Mayewski, J. Ren and Q. Yang. 2000. Climatological significance of an ice core net-accumulation record at Mt. Qomolangma (Everest). Chinese Sci. Bull., 45(3), 259-264.

Houghton, J.T. and 7 others. 2001. Climate change 2001: the scientific basis. Contribution of Working Group I to the Third Assessment Report of the Intergovernmental Panel on Climate Change. Cambridge, etc., Cambridge University Press.

Kadota, T., K. Fujita, K. Seko, R.B. Kayastha and Y. Ageta. 1997. Monitoring and prediction of shrinkage of a small glacier in the Nepal Himalaya. Ann. Glaciol., 24, 90-94. 
Kang, S., C.P. Wake, D. Qin, P.A. Mayewski and T. Yao. 2000. Monsoon and dust signals recorded in Dasuopu glacier, Tibetan Plateau. J. Glaciol., 46(153), 222-226.

Oerlemans, J. 2005. Extracting a climate signal from 169 glacier records. Science, 308(5722), 675-677.

Paterson, W.S.B. 1994. The physics of glaciers. Third edition. Oxford, etc., Elsevier.

Qin, D., ed. 2002. Summary report of assessment on environment change in West China. In Qin, D., ed. Assessment on environment change in West China. Synthesis Volume. Beijing, Science Press, 1-80. [In Chinese.]

Qin, D., ed. 2005. Climate and environment changes in China. Vol. 1. Beijing, Science Press. [In Chinese with English summary.]

Qin, D. and 9 others. 2000. Evidence for recent climate change from ice cores in the central Himalaya. Ann. Glaciol., 31, 153-158.

Qin, D. and 6 others. 2002. Preliminary results from the chemical records of an $80.4 \mathrm{~m}$ ice core recovered from East Rongbuk Glacier, Qomolangma (Mount Everest), Himalaya. Ann. Glaciol., 35, 278-284.

Ren, B. 1988. Recent variations of modern glaciers in China. In Shi, Y., ed. Introduction of glaciers in China. Beijing, Science Press, 171-186. [In Chinese.

Seko, K., H. Yabuki, M. Nakawo, A. Sakai, T. Kadota and Y. Yamada. 1998. Changing surface features of Khumbu Glacier, Nepal Himalayas revealed by SPOT images. Bull. Glacier Res., 16, 33-41.

Shi, Y.F., ed. 2003. An assessment of the issues of climatic shift from warm-dry to warm-wet in Northwest China. Beijing, Meteorological Press. [In Chinese with English abstract.]

Shi, Y., M. Huang and B. Ren. 1988. An introduction to the glaciers in China. Beijing, Science Press. [In Chinese]

Shi, Y., Y. Shen and R. Hu. 2002. Preliminary study on signal, impact and foreground of climatic shift from warm-dry to warm-humid in northwest China. J. Glaciol. Geocryol., 24(3), 219-226.

Thompson, L.G., T. Yao, E. Mosley-Thompson, M.E. Davis, K.A. Henderson and P. Lin. 2000. A high-resolution millennial record of the south Asian monsoon from Himalayan ice cores. Science, 289(5486), 1916-1919.
Tian, L., V. Masson-Delmotte, M. Stievenard, T. Yao and J. Jouzel. 2001. Tibetan Plateau summer monsoon northward extent revealed by measurements of water stable isotopes. J. Geophys. Res., 106(D22), 28,081-28,088.

Tian, L. and 7 others. 2003. Oxygen-18 concentrations in recent precipitation and ice cores on the Tibetan Plateau. J. Geophys. Res., 108(D9), 4293. (10.1029/2002JD002173.)

Wang, S., D. Gong, P. Zhai, J. Cau and Q. Mu. 2002. Climate change. In Wang, S. and G. Dong, eds. Environmental characteristics and change in West China. (Vol. 1 of Assessment on environment change in West China, ed. Qin, D.)Beijing, Science Press, 29-72. [In Chinese.]

Yamada, T. and 7 others. 1992. Fluctuations of the glaciers from the 1970s to 1989 in the Khumbu, Shorong and Langtang regions, Nepal Himalayas. Bull. Glacier Res., 10, 11-19.

Yao, T., J. Pu, N. Wang and L. Tian. 1999. A new type of ice formation zone found in the Himalayas. Chinese Sci. Bull. 44(5), 469-473.

Yao, T., K. Duan and L. Tian. 2000. Glacial accumulation record in the Dasuopu ice core and Indian summer monsoon rainfall in the past 400 years. Sci. China D, 30(6), 619-627.

Yao, T. and 9 others. 2002. Temperature and methane records over the last $2 \mathrm{ka}$ in Dasuopu ice core. Sci. China D, 45(12), 1068-1074.

Yao, T.D., Y.Q. Wang, S.Y. Liu, J.C. Pu, Y.P. Shen and A.X. Lu. 2004. Recent glacial retreat in High Asia in China and its impact on water resource in Northwest China. Sci. China D, 47, 1065-1075.

Zhang, D. 2001. The modern glaciological environment in the central Himalayas and Indian monsoon. (PhD thesis, Cold and Arid Regions Environmental and Engineering Research Institute.)

Zhang, D., D. Qin and S. Hou. 2003. Climatic significance of $\delta^{18} \mathrm{O}$ record of a $80.36 \mathrm{~m}$ ice core from East Rongbu Glacier in Mt. Qomolangma. Sci. China D, 33(3), 264-270. [In Chinese.]

Zhao, Z., X. Gao, M. Tang and Y. Xu. 2002. Projections of climate change. In Ding, Y., ed. Projections of environment change in West China. (Vol. 2 of Assessment on environment change in West China, ed. Qin, D.) Beijing, Science Press, 16-46. [In Chinese.] 